\title{
MicroGeneSys goes on trial
}

Washington. The US Army is to carry out the world's largest trial of a therapeutic AIDS vaccine in the face of fierce opposition from many AIDS researchers, after agreeing supply of the vaccine from the Connecticut company, MicroGeneSys.

The Army and MicroGeneSys appear to have outwitted AIDS activists and scientists who thought they had blocked the controversial single-product trial last April, when, as a result of White House intervention, responsibility for the trial was transferred from the Army to the National Institutes of Health (NIH)

But NIH's plans for a comparative trial of several therapeutic vaccines had to be abandoned in June, when MicroGeneSys refused to provide its vaccine free (see $\mathrm{Na}$ ture 363, 294, 1993). The Army trial will now test only the MicroGeneSys vaccine, which will be paid for by its commercial partner, Philadelphia-based Wyeth-Ayerst.

Final details of the trial have still to be negotiated with the Food and Drug Administration. But 5,000-10,000 HIV-infected patients will probably be injected with either vaccine or placebo over four years. The Army will assess the outcome.

Frank Volvovitz, president of MicroGeneSy says the agreement with the army is "fortunate", and that the company's

vaccine is "the only one ready to enter Phase III trials". He dismisses NIH's opposition to the Army's trial as "really about protecting turf, not to do with AIDS": a high-level NIH panel has unanimously agreed that there are no scientific grounds for the trial.

Volvovitz denies that recent events have undermined the scientific basis of the planned trial (see Nature 364, 374; 1993). But he concedes that "there is a prevailing opinion [among senior AIDS researchers] that this is the case". He says that the trial's basis has been "no more undermined than the use of surrogate markers". The huge trial will look to patient survival as its main marker, and not CD4 counts.

Wyeth-Ayerst will pay MicroGeneSys an undisclosed sum, believed to be between $\$ 5$ million and $\$ 10$ million, to cover the cost of producing vaccine for the trial. A spokesperson for Wyeth-Ayerst says that the company did not offer to pay for the vaccine when NIH wanted to use it in the multipleproduct trial because "NIH never asked us". Opponents of the single-vaccine trial take comfort from the fact that Wyeth and not the taxpayer is paying this sum. But the fact remains that the Army and MicroGeneSys have both got almost exactly what they wanted.

The trial will probably start in the new

\section{Supercollider tunnelling stops}

Dallas. The last of the tunnelling machines boring the main, 54-mile circumference ring to house the Superconducting Super Collider (SSC) will grind to a halt next week, to await Congress's final verdict on whether the $\$ 9$ billion project can proceed.

Two machines have stopped and the two others are proceeding to positions where they too can safely come to a halt, probably on 30 August and 4 September respectively. In common with other construction contracts, the tunnelling is being suspended as cash dries up and the SSC conserves what money it has to pay its 1,700 core staff.

The project director, Roy Schwitters, says he remains in the dark about the plans of Energy Secretary Hazel O'Leary to appoint a new lead contractor to manage project construction (see Nature 364, 567; 1993). "I don't know what model they are considering", he says. But he hopes that the changes will leave most of the existing project management intact, including his own position. "I don't anticipate leaving the project", he says. "I'm interested in seeing the SSC built, and I'll do anything to further that goal, whether that means staying or not staying."

Opinion is divided at the SSC's bustling design laboratories in the suburbs of Dallas, and on the sprawling construction sites around Waxahachie, just south of the city, as to whether the project will survive. Scientists are proceeding on the basis that the project will survive, but some local people are under the (mistaken) impression that Washington has already decided to kill it.

For his part, Schwitters considers it "likely" that the SSC will survive. "I think there are a lot of serious people in Congress who are beginning to fathom the consequences of stopping this", he says. The House of Representatives has voted not to fund the project (see Nature 363, 6; 1993) but the Senate will probably support it next month, leaving the final decision in the hands of an unpredictable conference between leaders of the two houses.

Schwitters warns that uncertainty over the project's future has prevented the management from developing plans to stretch out the project, as it was asked to do by the Clinton administration in the spring. "That work is not where it should be", he says, "so there is going to be a multi-month effort to re-invent the project" if funding is indeed resumed. "What the impact is on the final completion date I can't tell you. I sense we could maintain the 2002 date suggested by Clinton; the [original] 1999 date is very hard to imagine."

Colin Macilwain year, even if Congress decides to investigate how the $\$ 20$ million cost of the trial became earmarked to the Army last autumn. Volvovitz says he would "welcome as much investigation as possible into the whole area".

Tony Fauci, director of the National Institute of Allergies and Infectious Diseases and the chief AIDS researcher at NIH, declined to comment on the outcome: "We gave our recommendations, and have nothing more to add."

Colin Macilwain

\section{New agency pools biology research}

Washington. Biological research scattered throughout the US Department of the Interior will in October be brought under the umbrella of a new agency, the National Biological Survey (NBS). One task of the agency will be to compile an inventory of every ecosystem in the United States and its plant and animal species.

NBS will regroup the Department of the Interior's budget for biological research with an expected small increase to $\$ 164$ million; Congress is expected to approve the NBS budget next month. Similarly its staff will be drawn from a reorganization of the 1,700 scientists in its various laboratories. The new structure should use resources better, by reducing fragmentation and duplication, and provide a clearer long-term strategy.

"What we're aiming for is good science, science that is unbiased and solid enough to bring everyone together at the negotiating table talking the same language", says NBS spokeswoman Trudy Harlow. One way in which independence and objectivity will be encouraged is by separating scientists from decision-making and enforcement.

Bruce Babbitt, Secretary of the Interior, sees good science as the means to streamline ecosystem management and to avoid "environmental train wrecks". He says a recent court dispute - between environmentalists and the timber industry over the spotted owl in the Pacific Northwest - would not have happened if the department had collected more long-term scientific data on such things as population counts.

But critics say more information is not enough. "NBS will only generate more paperwork in Washington. It's purely cosmetic", says Jerry Taylor of the CATO Institute, a conservative Washington think-tank: "The only way to prevent extinction is to provide economic incentives to landowners, to make it in their best interest to comply with species protection laws."

Even environmentalists, who applaud the creation of the NBS, agree. "All the databases in the world won't help until we complement the Endangered Species Act with more comprehensive initiatives to maintain the natural habitat", says Mark Shaffer of the Wilderness Society. Susan Greene 